\title{
SEROPREVALENCE AND RISK FACTORS OF CHLAMYDIA ABORTUS INFECTION IN AWASI SHEEP IN HAMA GOVERNORATE IN THE MIDDLE REGION OF SYRIA
}

\author{
M. F. AL-TABBAA, A. K. KALB ALLOUZ AND Y. ALOMAR \\ Department of Animal Diseases, Faculty of Veterinary Medicine, University of \\ Hama, Hama, Syria
}

Received: 17 October 2020; Accepted: 27 October 2020

\begin{abstract}
Chlamydia abortus is an obligate intracellular Gram-negative and an important pathogenic bacteria, which can infect animals and humans. 312 blood samples were collected from 17 flocks of Awasi sheep in the down-town and province in Hama governorate between February 2019 and January 2020. The total number of sheep in the study flocks were 3715 including 2972 pregnant sheep. Seropositive cases of $C$. abortus antibodies were found in 5 of 17 study flocks with a percent of $29.41 \%$. The overall prevalence was $(36 / 312)$ $11.53 \%$ as positive to specific antibodies of $C$. abortus using ELISA test, which ranged between (0-100\%) in tested samples from evry flock in Hama governorate and the seroprevalence in downtown was $14.285 \%, 16.666$ in Koumhana, 33.333\% in Almbarkat and $33.333 \%$ in Tal Altut, and $100 \%$ in Maar Shoor. The higher prevalence of OEA was reported in the winter season comparing with other Seasons $(\mathrm{OR}=2.52)$ and the riskiest ages in OEA were ages between $2-4$ years.
\end{abstract}

Keywords: Chlamydia abortus, Ovine Enzootic Abortion, Seroprevalence, Risk Factors.

\section{INTRODUCTION}

Chlamydial abortion in ewes or ovine enzootic abortion [OEA]) is an important disease in sheep caused by Chlamydia abortus. Ovine Chlamydiosis causes abortion in the last period of pregnancy and may cause serious economic loss in sheep-breeding areas and threaten sheep industry development worldwide, particularly where herds are

Corresponding author: M. F. AL-TABBAA

E-mail address: p.m.f.tz7z@gmail.com

Present address: Department of Animal Diseases, Faculty of Veterinary Medicine, University of Hama, Hama, Syria closely congregated during the last 2-3 weeks of gestation (Aitken and Longbottom, 2007).

Infected ewes may show no clinical symptoms before abortion, but behavioral changes, a vulval and vaginal secrations may be observed in ewes within the last 48 hours of gestation. Pathogenesis sgins occur usually at the end of three months of pregnancy period coincident with a phase of rapid fetal growth when the $C$. abortus invasion of placentomes produces placental damge with progressively diffuse inflammatory response and tissue necrosis. Milder Pathogenesis sgins may occur in the fetal liver and lung and sometimes 
hypoxic brain damage in cases with severe placental damage (Buxton et al., 2002; Longbottom et al., 2013 and OIE, 2018).

Chlamydia abortus (C. abortus) is causing ovine enzootic abortion (OEA), and recognized as main cause of abortion in sheep and lamb loss throughout the world. C. abortus manifests an assortment of symptoms which mainly minify the economic feasibility of flocks such as endometritis, premature of weakly lambs, stillborn lambs, orchitis, epididymitis, and seminal vesiculitis. Pneumonia, encephalomyelitis, arthritis, and conjunctivitis have been other illness sgins of OEA. In some regions in the world like united kingdom $C$. abortus is considered as the principal agent of death in lambs and leading to losses rated about 20 million dollars yearly (Longbottom et al., 2013).

The family Chlamydiaceae is an obligate intracellular gram-negative and pathogen bacteria which can infect animals and humans. It has a single genus chlamydia that comprises eleven species which include: $C$. trachomatis and C. pneumonia (humans pathogen), and some of them can infect animals such as $C$. suis (swine), $C$. muridarum (mouse), $C$. psittaci (avian), $C$. felis (cat), C. caviae (guinea-pig), $C$. pecorum (sheep, cattle and, koala), $C$. avium and $C$. gallinaceae (both infect birds), and especially $C$. abortus which can infect sheep, goat, cattle and humans (Sachse et al., 2015).

The serological diagnostic and identifaction of $C$. abortus antibodies in sheep sera can be detected through using serological tests such as immunofluorescence test, complement fixation test (CFT), or enzyme-linked immunosorbent assay (ELISA) as lacks specificity test (Griffiths et al., 2006). C. abortus can be detected the positive serasamples using a complement fixation test or enzyme-linked immunosorbent assay (Masala et al., 2007).

Recently, a new indirect ELISA based on POMP90 has been commercialized and shown to be both sensitive and specific for C. abortus, in particular in differentiating animals infected with $C$. pecorum (Anon, 2015; Essig and Longbottom, 2015).

Abortion probably results from a combination of impairment of maternofetal nutrient and gaseous exchange, disruption of hormonal regulation of pregnancy, and induced cytokine aggression (Entrican, 2002).

\section{MATERIALS AND METHODS}

\section{Serological diagnostic of Ovin enzootic Abortion:}

The current study was carried out within the period of February 2019 - January 2020 on 312 samples taken from 17 sheep herds, in the Hama governorate in the middle region of Syria. Samples of blood were taken from sheep between 1 - 5 years using a random technique. In the epidemiological term, the overall number of herds was counted by dividing the overall individual sample volume by the numeral of sheep to be sampled from every herd. The sera were obtained by leaving blood specimens at room temperature for separating of serum which stocked in Eppendorf tubes at $-20{ }^{\circ} \mathrm{C}$ till further tested. Specimens were examined for the detection of specific antibodies to $\mathrm{C}$. abortus employing the indirect ELISA kit (ID-Vet, Innovative Diagnostics Vet, Grabels, France).

\section{Method of testing:}

\section{ELISA test:}

The serum was examined for the detection of IgG antibodies for C. abortus employing the ID-Screen $C$. abortus multispecies 
indirect ELISA kit (ID-Vet, Innovative Diagnostics Vet, Grabels, France). The microtiter plates (96 wells) were provided plated with the recombinant protein. Results optical density (OD) was measured at $450 \mathrm{~nm}$ employing a microtiter plate reader. The final values were expressed as sample/positive control percentage (S/P $\%)$. Sera with S/P \% equal to or lower than $50 \%$ were considered negative, sera with an S/P \% between 50 and $60 \%$ were doubtful and sera with an S/P \% >60\% were considered positive. This ELISA assay uses a synthetic antigen from a major outer-membrane protein (Momp) specific to $\mathrm{C}$. abortus which reduces the frequency of non-specific reaction.

\section{Epidemiological data collection:}

The main data which depended on flock size, giographical regions of the animals, age, year seasons, stage of abortion, stillborn, death in young lambs, born of weakly lambs, therapy of newly purchased sheep, cleaning methods and use of disinfection materials, presence of other animals in the farm such as cats, dogs, birds, and farmworkers with contact to other farms were collected.

\section{Potential Risk factors analysis:}

Differences in the Seroprevalence of $C$. abortus among Awase sheep of different geographical regions, season, and age was analyzed, and the Potential relationship and risk factors of $C$. abortus infection in sheep were discussed by statistical significance analysis. $\mathrm{P}<0.5$ was considered statistical significant. Each factor was analyzed with odds ratios (ORs) and $95 \%$ confidence intervals $(\mathrm{Cls})$ in the study. All statistical significant analyses were performed by SAS (Statistical Analysis Sestem, Version 9.1) (Zhang et al., 2016 and Zheng et al., 2016).

\section{RESULTS}

In this study, $36(11.53 \%)$ out of 312 tested serum samples from Awasi Sheep in the Hama governorate were seropositive for C. abortus antibodies and 276 $(88.46 \%)$ samples were seronegative by ELISA-Test (Figure 1).

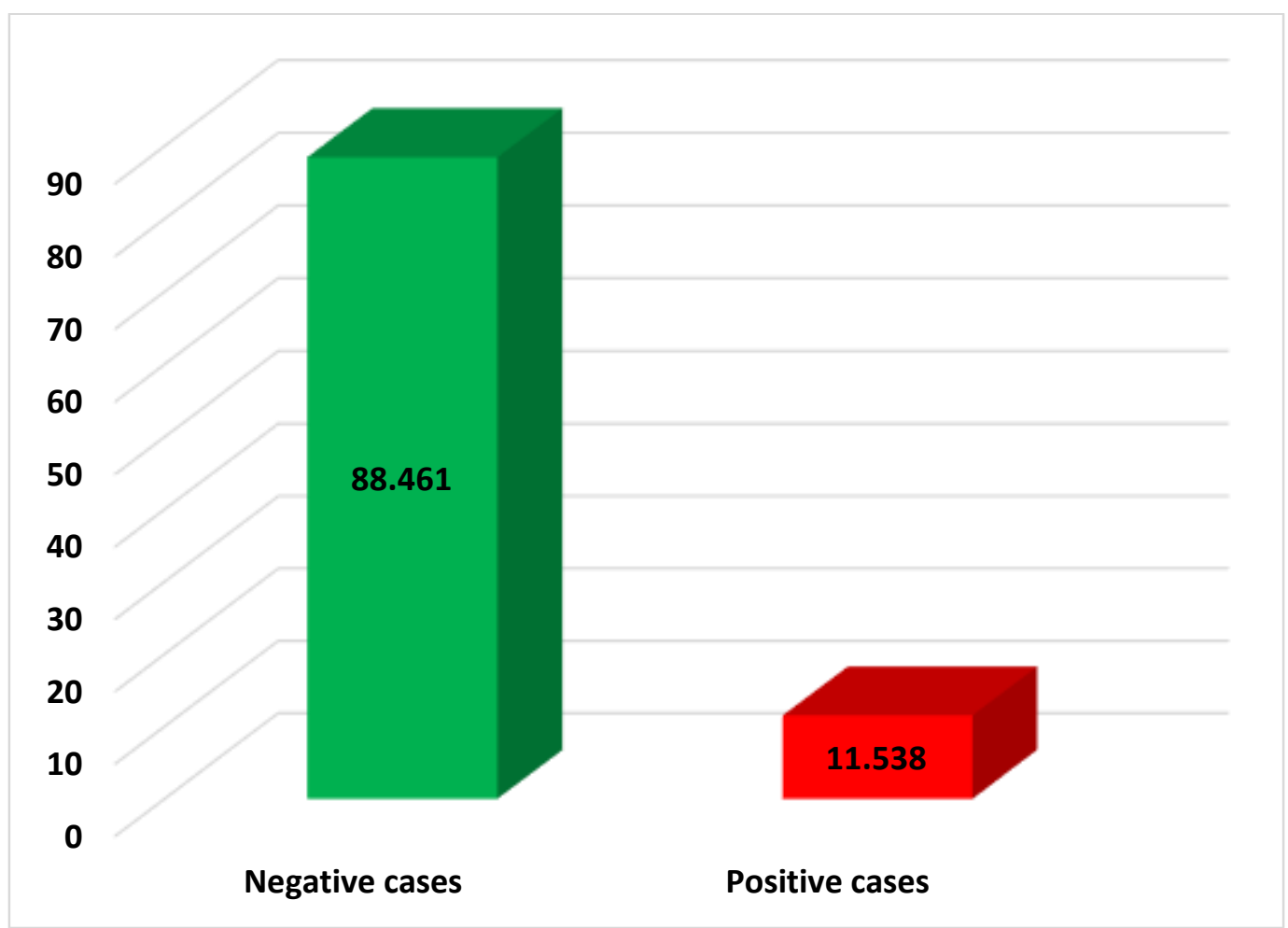

Figure 1: Seroprevalence of $C$. abortus antibodies in tested sheep in the Hama governorate. 
Seropositive sheep were found in 5 out of 17 (29.41\%) flocks with Seroprevalence of $C$. abortus antibodies ranging from $0 \%$ to $100 \%$ in individual flocks (Figure 2).
The seroprevalence was different among regions. It was $14.285 \%$ in downtown, 16.666 in Koumhana, $33.333 \%$ in Almbarkat, and $33.333 \%$ in Tal Altut, $100 \%$ in Maar shoor (Table $1 \&$ Figure 3).

Table 1: Seroprevalence of $C$. abortus antibodies in study regions in Hama governorate.

\begin{tabular}{ccccc}
\hline Regions & $\begin{array}{c}\text { Tested blood } \\
\text { sample }\end{array}$ & $\begin{array}{c}\text { Positive } \\
\text { cases }\end{array}$ & $\begin{array}{c}\text { Negative } \\
\text { Cases }\end{array}$ & $\begin{array}{c}\text { Prevalence } \\
\mathbf{\%}\end{array}$ \\
\hline Town Center & $\mathbf{4 2}$ & $\mathbf{6}$ & $\mathbf{3 6}$ & $\mathbf{1 4 . 2 8 5}$ \\
\hline Gpren & 18 & 0 & 18 & 0 \\
\hline Koumhana & $\mathbf{3 6}$ & $\mathbf{6}$ & $\mathbf{3 0}$ & $\mathbf{1 6 . 6 6 6}$ \\
\hline Kana Hasna & 18 & 0 & 18 & 0 \\
\hline ALmbarkat & $\mathbf{1 8}$ & $\mathbf{6}$ & $\mathbf{1 2}$ & $\mathbf{3 3 . 3 3 3}$ \\
\hline AenAlbad & 18 & 0 & 18 & 0 \\
\hline Altaeba & 18 & 0 & 18 & 0 \\
\hline Morek & 18 & 0 & 18 & 0 \\
\hline Maar Shoor & $\mathbf{1 2}$ & $\mathbf{1 2}$ & $\mathbf{0}$ & $\mathbf{1 0 0}$ \\
\hline Alswaek & 12 & 0 & 12 & 0 \\
\hline Kasone & 12 & 0 & 12 & 0 \\
\hline Tal Aldraah & 12 & 0 & 12 & 0 \\
\hline Alsapora & 6 & 0 & 6 & 0 \\
\hline Akerbat & 18 & 0 & 18 & 0 \\
\hline ImAlamad & 18 & 0 & 18 & 0 \\
\hline Alsaan & 18 & 0 & 18 & $\mathbf{3 3 . 3 3 3}$ \\
\hline Tal Altut & $\mathbf{1 8}$ & $\mathbf{6}$ & $\mathbf{1 2}$ & $\mathbf{1 1 . 5 3 8}$ \\
\hline TOTAL & $\mathbf{3 1 2}$ & $\mathbf{3 6}$ & $\mathbf{2 7 6}$ &
\end{tabular}

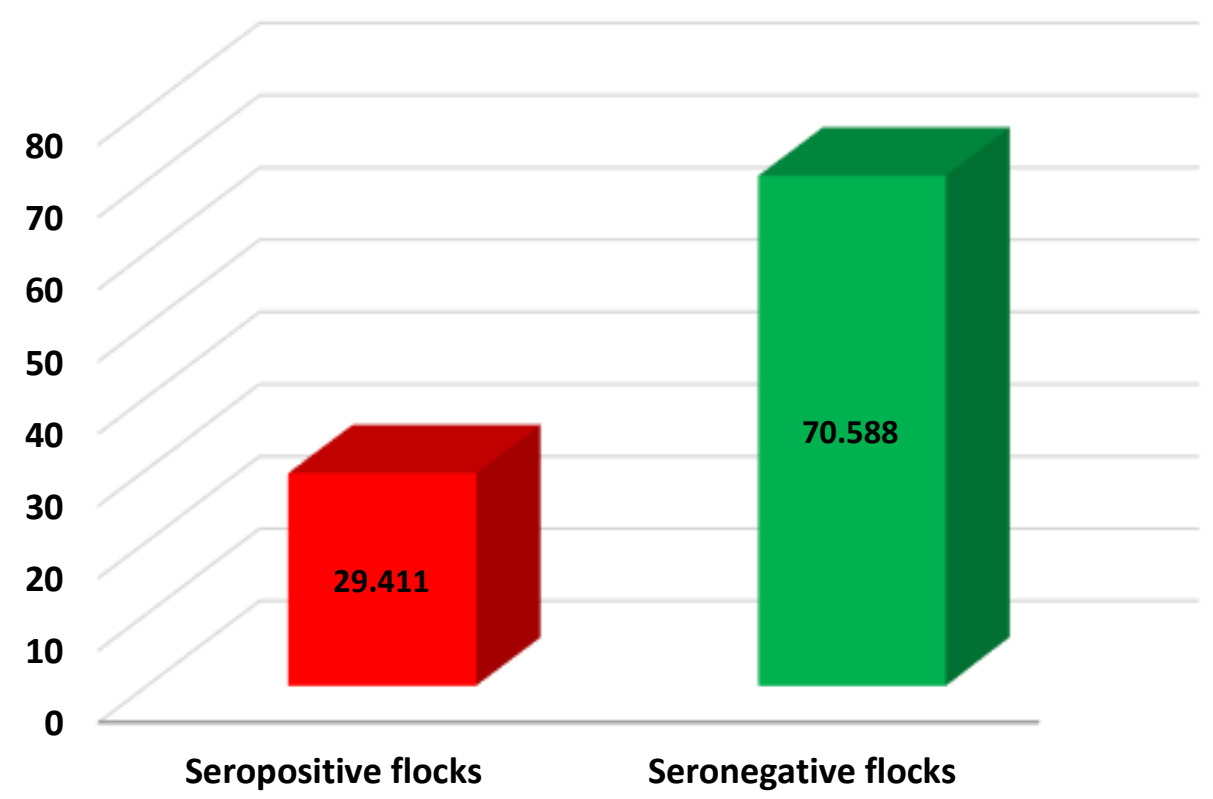

Figure 2: Seroprevalence of C. abortus antibodies in study flocks in Hama governorate. 


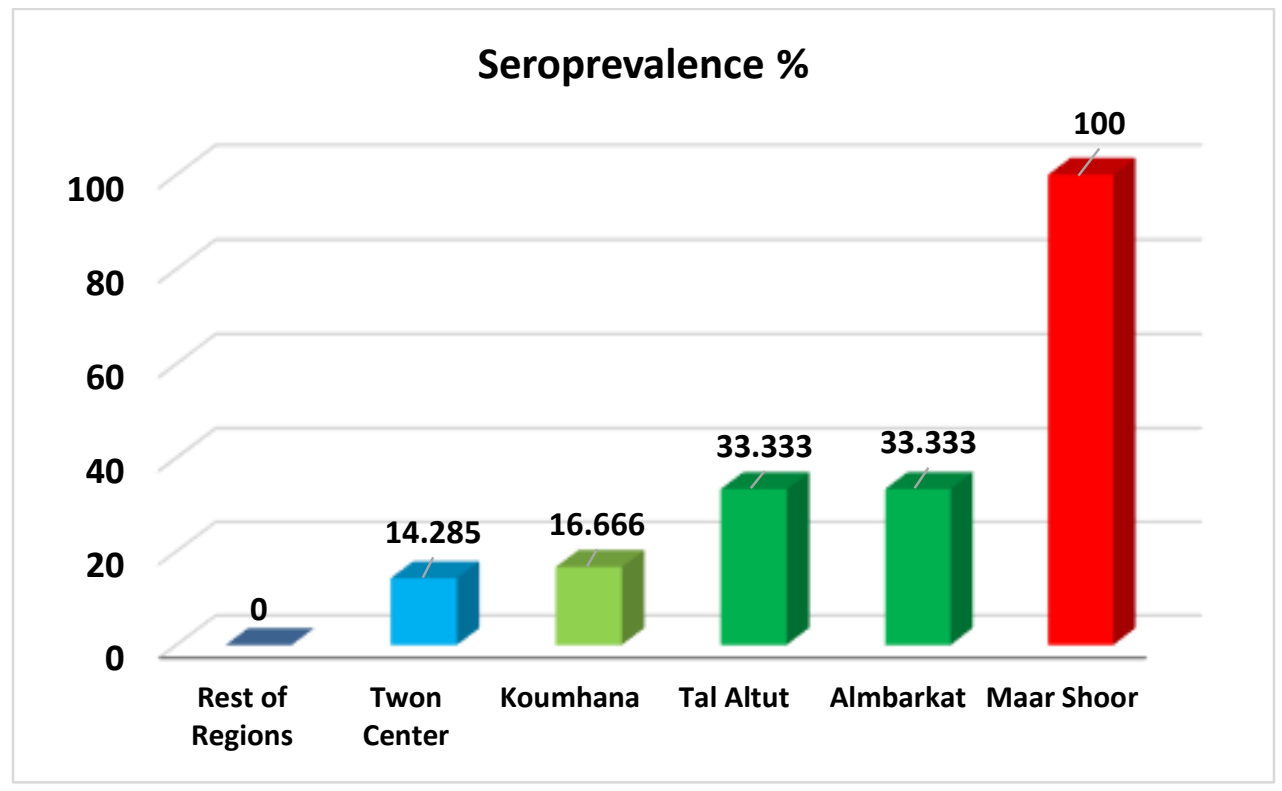

Figure 3: Seroprevalence results of $C$. abortus antibodies of the 312 tested serum samples.

A highly significant correlation has been $(\mathrm{p}<0.0001)$. Prevalence proportions detected between the seroprevalence of varied between 0 and $1.51 \%$ (Table 2 ). infection and the geographic location

Table 2: Odds ration of the impact of the region according to Prevalence of the disease.

\begin{tabular}{cccc}
\hline Regions & $\begin{array}{c}\text { Lower limit of } \\
\text { OR 95\% }\end{array}$ & OR & Upper limit of OR 95\% \\
\hline Town Center & $\mathbf{0 . 6 7}$ & $\mathbf{0 . 0 1 3}$ & $\mathbf{1 . 0 0}$ \\
\hline Gpren & 0.00 & 0.00 & 0.00 \\
\hline Koumhana & $\mathbf{0 . 0 8}$ & $\mathbf{0 . 0 1 2}$ & $\mathbf{1 . 0 1}$ \\
\hline Kana Hasna & 0.00 & 0.00 & 0.00 \\
\hline ALmbarkat & $\mathbf{0 . 1 2}$ & $\mathbf{1 . 5 1}$ & $\mathbf{0 . 2 1}$ \\
\hline AenAlbad & 0.00 & 0.00 & 0.00 \\
\hline Altaeba & 0.00 & 0.00 & 0.00 \\
\hline Morek & 0.00 & 0.00 & 0.00 \\
\hline Maar Shoor & $\mathbf{0 . 0 5 2}$ & $\mathbf{0 . 0 7 3}$ & 0.00 \\
\hline Alswaek & 0.00 & 0.00 & 0.00 \\
\hline Kasone & 0.00 & 0.00 & 0.00 \\
\hline Tal Aldraah & 0.00 & 0.00 & 0.00 \\
\hline Alsapora & 0.00 & 0.00 & 0.00 \\
\hline Akerbat & 0.00 & 0.00 & 0.00 \\
\hline ImAlamad & 0.00 & 0.00 & 0.00 \\
\hline Alsaan & 0.00 & 0.00 & $\mathbf{2 . 0 6 1}$ \\
\hline Tal Altut & $\mathbf{1 . 0 0}$ & $\mathbf{1 . 5 1}$ & \\
\hline
\end{tabular}


No significant difference has been observed between the seroprevalence of OEA and different age groups ( $p>0.05)$. The highest prevalence rate has been recorded in ewes aged between 2 years and 35 months. The riskiest ages in OEA were ages between $2-4$ years (Table 3 ).

Table 3: Odds ration of the effect of some Risk factors season and age associated with disease occurrence.

\begin{tabular}{|c|c|c|c|c|c|c|}
\hline Category & $\begin{array}{c}\text { No. of } \\
\text { ovine } \\
\text { examined }\end{array}$ & $\begin{array}{c}\text { No. of } \\
\text { ovine } \\
\text { positive }\end{array}$ & $\begin{array}{l}\text { Prev. \% } \\
(95 \% \text { CI })\end{array}$ & $\begin{array}{l}\text { Upper limit } \\
\text { of OR } 95 \%\end{array}$ & $\begin{array}{c}\text { Odds } \\
\text { Ratio } \\
\text { OR }\end{array}$ & $\begin{array}{l}\text { Lower limi } \\
\text { of OR } 95 \%\end{array}$ \\
\hline $\begin{array}{l}\text { Season } \\
\text { summer }\end{array}$ & 77 & 14 & $\begin{array}{c}18.18 \\
13.82-22.54\end{array}$ & 2.011 & 0.4631 & 0.325 \\
\hline $\begin{array}{l}\text { Season } \\
\text { spring }\end{array}$ & 85 & 6 & $\begin{array}{c}7.05 \\
4.15-9.95\end{array}$ & 1.01 & 0.172 & 0.143 \\
\hline $\begin{array}{l}\text { Season } \\
\text { winter }\end{array}$ & 75 & 16 & $\begin{array}{c}21.33 \\
16.69-25.97\end{array}$ & 2.52 & 1.87 & 1.00 \\
\hline $\begin{array}{l}\text { Season } \\
\text { autumn }\end{array}$ & 75 & $\mathbf{0}$ & $\mathbf{0}$ & 0.00 & 0.00 & 0.00 \\
\hline Age $(y r) \leq 2$ & 100 & 12 & $\begin{array}{c}12 \\
\text { 8.32-15.68 }\end{array}$ & 2.51 & 1.01 & 0.991 \\
\hline$\underset{(y r)>2 \leq 4}{\text { Age }}$ & 100 & 14 & $\begin{array}{c}14 \\
10.07-17.93\end{array}$ & 3.44 & 3.011 & 2.51 \\
\hline Age $(y r)>4$ & 112 & 10 & $\begin{array}{c}8.92 \\
5.69-12.15\end{array}$ & 1.00 & 0.883 & 0.51 \\
\hline Total & 312 & 36 & $\begin{array}{c}11.53 \\
7.92-15.14\end{array}$ & - & - & - \\
\hline
\end{tabular}

From the above table, it was reported the higher prevalence of OEA in the winter season comparing with other Seasons $(\mathrm{OR}=2.52)$. There were no reported cases in the autumn season. The riskiest ages in OEA were ages between $2-4$ years.

\section{DISCUSSION}

Enzootic abortion in sheep is considered under the list of legally reported cases in Syria. This study reported that rate of abortion resulted from $C$. abortus was $11.538 \%$. Positive antibodies were 
present in 5 Flocks of 17 Flocks as a percent $29.41 \%$ of study Flocks.

Many studies were confirmed positive Cases of C.abortus in sheep and small livestock in the middle east and Asia. The Figures results of the prevalence reported in the present study were fitting with reported results of (Al-Dabagh et $a l ., 2014)$ in Iraqi sheep $(11.2 \%)$ using ELISA test. Also, current results were fitting with the results of (Mikaeel et al., 2016) in goat Flocks in Iraqi regions.

The same figures points were reported in a sheep flock in the northern and eastern regions of Turkey (13.98\%) using indirect ELISA test (Gokce et al., 2007).

Similar results were reported in northern Palestine, where reported positive cases in Awasi sheep as $13.7 \%$ seroprevalence (Jalboush et al., 2017).

lower figures of seroprevalence of $C$. abortus were reported in north of Iraq (3.33\%) (Arif et al., 2020), and in the Riyadh region $(7.52 \%)$ (Al-Jumaah and Hussein, 2012) and (0.75\%) in Madina (Shabana and Krimly, 2020) both in Saudi Arabia.

Lower prevalence level reported in regional regions like Turkey, using indirect ELISA test in Turkish sheep as a percentage (5.38\%) (Otlu et al., 2007).

However, a higher level of prevalence was reported in Awasi sheep and Baldy goat in Jordan in the Al-Mafrak region as (21.8\%) (AL-Qudah et al., 2004).

Wide world, prevalence level was higher in the western region of China (18.65\%) using indirect hemagglutination test (Qin et al., 2014).

The various between proportions results may be justified by the variety of diagnostic test techniques (Wilson et al., 2009).

Furthermore, the Variant between figures among different scientific studies may be returned to the type of pastures, water sources, and contacts factor between infection and free disease animals (Rodolakis and Laroucau, 2015).

As long as, many filed cases of C.abortus are not diagnosed, as the main cause of abortion resulted from C.abortus may estimate in $10 \%$ in the USA, this because the filed diagnosis can be facing many difficulties, as long as clinical signs and lesion linked to $C$. abortus are not defined yet (Essig and Longbottom, 2015).

The present study considered the first study in Syria that determined risk factors associated with c. abortus in sheep flocks in Syria.

The most popular risk factors reported in the study were seasonal variation and age which corresponding with the results of (Hu et al., 2018) in China.

There was a correlation between infection and data of abortion in infected sheep and entry male sheep in the flock as likelihood risk factors ( $\mathrm{Hu}$ et al., 2018).

In the study reported in Brazil, the geography position was a risk factor, and 
infection in males was more affected compared with females, with no significant correlation between each other p>0.01 (Pinheiro et al., 2010).

\section{REFERENCES}

Aitken, I.D. and Longbottom, D. (2007): Chlamydial abortion. In: Diseases of Sheep Fourth Edition. Blackwell Scientific Ltd., Oxford, UK, 105112.

Al-Dabagh, I.I.; Jasim, B.M. and Jarjees, M.T. (2014): Seroprevalence of antibodies to toxoplasmosis, brucellosis and chlamydiosis in abortive sheep in Nineveh governorate, Iraq. Iraqi Journal of Veterinary Sciences, Vol. 28, No. 1, (21-25).

Al- Jumaah, R.S. and Hussein, M.F. (2012): Serological prevalence of ovine and caprine chlamydiophilosis in Riyadh region - Saudi Arabia. Afr. J. Microbiol. 2012; 6: 2654-2658.

AL-Qudah, K.M.; Sharif, L.A.; Raouf, R.Y.; Hailat, N.Q. and AL-Domy, F.M. (2004): Seroprevalence of antibodies to Chlamydophila abortus shown in Awassi sheep and local goats in Jordan. Veterinarni Medicina, 49(12): 460-466.

ANON (2015): Diagnostic test for ovine chlamydiosis. Vet. Rec., 176, 393.

Arif, E.D.; Saeed, N.M. and Rachid, S.K. (2020): Isolation and Identification of Chlamydia abortus from Aborted Ewes in Sulaimani Province, Northern Iraq. Polish Journal of Microbiology, Vol. 69, No 1.

Buxton, D.; Anderson, I. E.; Longbottom, D.; Livingstone, M.; Wattegadera, $S$. and Entrican, G. (2002): Ovine chlamydial characterization abortion: of the inflammatory immune response in placental tissues. J. Comp. Pathol., 127, 133-141.

Entrican, G. (2002): Immune regulation during pregnancy and hostpathogen interactions in infectious abortion. J. Comp. Pathol., 126, 7994.

Essig, A. and Longbottom, D. (2015): Chlamydia abortus: New aspects of infectious abortion in sheep and potential risk for pregnant women. Curr. Clin. Microbiol. Reports, 2, 22-34.

Gokce, I.H.; Kacar, C.; Genc, O. and sozmen, M. (2007): Seropevalance of chlamydophila abortus in aborting ewes and dairy cattle in the north-east part of turkey. Bull. Vet. Inst. Pulawy, 51, 9-13.

Griffiths, E.; Ventresca, M.S. and Gupta, R.S. (2006): BLAST screening of chlamydial genomes to identify signature proteins that are unique for the Chlamydiales, Chlamydiaceae, Chlamydophila and Chlamydia groups of species. BMC Genomics. 7: 14.

Hu, S.F.; Li, F.; Zheng, W.B. and Liu, G.H. (2018): Seroprevalence and Risk Factors of Chlamydia abortus Infection in Goats in Hunan Province, Subtropical China. Vector-Borneand Zoonotic Diseases, Volume XX, Number XX.

Jalboush, N.; Atalla, H. and Alzuheir, I. (2017): Detection of Chlamydophila abortus antibody in active reproductive rams in sheep herds in northern Palestine. Revue Méd. Vét., 168, 7-9, 192-196.

Longbottom, D.; Livingstone, M.; Maley, S.; Van Der Zon, A.; Rocchi, M.; Wilson, K.; Wheelhouse, $N$.; Dagleish, M.; Aitchison, K.; Wattegedera, S., Nath, M.; 
Entrican, G. and Buxton, D. (2013): Intranasal infection with Chlamydia abortus induces dosedependent latency and abortion in sheep. PLo S One, 8, e57950.

Masala, G.; Porcu, R.; Daga, C.; Denti, S.; Canu, G.; Patta, C. and Tola, S. (2007): Detection of pathogens in ovine and caprine abortion samples from Sardinia, Italy, by PCR. Journal of Veterinary Diagnostic Investigation, 19, 96-98.

Mikaeel, F.B.; Taha, Z.M.A. and Omer, L.T. (2016): Seroprevalence of Chlamydophila abortus in goat farms in Duhok Province-Iraq. Alqadisiya Journal of vet. Med. Sci., Vol. 15, No. 1, 34- 37.

OIE: (Office International des Epizooties) Terrestrial Manual (2018): Chapter 3.7.5., Enzootic abortion of ewes (ovine chlamydiosis). In: Manual of diagnostic testes and vaccines for terrestrial animals. World organization for animal health, pp. 1456-1465.

Otlu, S.; Sahin, M.; Unver, A. and Celebi, O. (2007): Detection of Brucella melitensis and Chlamydophila abortus antibodies in aborting sheep in Kars province of turkey. Bull. Vet. Inst. Pulawy. 15:493-495.

Pinheiro, J.J.W.; Mota, R.A.; Piatti, R.M.; Oliveira, A.A.; da Silva, A.M.; de Oliveira Abreu, S.R.; Anderlini, G.A. and Valenca, R.M. (2010): $\quad$ Seroprevalence of antibodies to Chlamydophila abortus in ovine in the state of Alagoas. Braziian Journal of microbiology, 41, 358-364.

Qin, S.Y.; Yin, M.Y.; Cong, W.; Zhou, D.H.; Zhang, X.X.; Zhao, Q.; Zhu, X.Q.; Zhou, J.Z. and Qian, A.D.
(2014): Seroprevalence and Risk Factors of Chlamydia abortus Infection in Tibetan Sheep in Gansu Province, Northwest China. Scientific World Journal Volume 2014, Article ID 193464, 6 pages.

Rodolakis, A. and Laroucau, K. (2015): Chlamydiaceae and chlamydial infections in sheep and goats. Veterinary Microbiology 181(1-2), 107-118.

Sachse, K.; Bavoil, P.M.; Kaltenboeck, B.; Stephens, R.S.; Кио, C.C.; Rossello-Mora, R. and and Horn, M. (2015): Emendation of the family Chlamydiaceae: proposal of a single genus, Chlamydia, to include all currently recognized species. Syst. Appl. Microbiol., 38, 99-103.

Shabana, I.I. and Krimly, R.A. (2020): Seroprevalence of some viral and bacterial zoonoses in domestic ruminnantsin Medina. J. Adv. Vet. Anim. Res., 791): 42-50.

Wilson, K.; Livingstone, $M . \quad$ and Longbottom, D. (2009): Comparative evaluation of eight serological assays for diagnosing Chlamydophila abortus infection in sheep. Vet. Microbiol., 135, 38-45.

Zhang, X.X.; Zheng, W.B.; Ma, J.G. and Yao Q.X. (2016): Occurrence and multilocus genotyping Giardia intestinalis assemblage $\mathrm{C}$ and $\mathrm{D}$ in farmedraccoon dogs, Nyctereutesprocyonoides in China. Parasit Vectors, 9: 471.

Zheng, W.B.; Cong, W.; meng, Q.F. and Ma, J.G. (2016): Seroprevalence and risk factors of toxoplasma gondii infection in farmed mink (Neovisonvison) in northeastern and eastern china. Vector Borne Zoonotic Dis., 16: 485-488. 
الاتتشار المصلي وعوامل الخطورة لعدوى المتدثرة المجهضة في أغنام العواس

\section{في محافظة حماة في المنطقة الوسطى في سوريا}

\section{محد فائز الطباع ، عبل الكريم قلب اللوز ، ياسر العدر}

E-mail: p.m.f.tz7z@gmail.com Assiut University web-site: www.aun.edu.eg

$$
\text { قسم أمر اض الحيوان في كلية الطب البيطري بجامعة حماة، حماة - سورية }
$$

المتدثرة المجهضة جر اثيم خلوية مجبرة سالبة الغرام ومن العو امل المسببة الهامة للعدوى في الحيوان و الانسان.

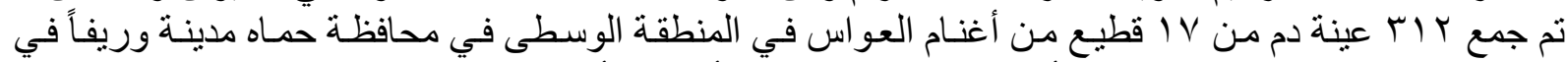

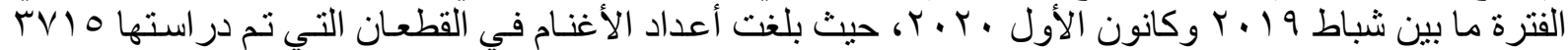

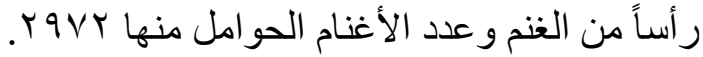

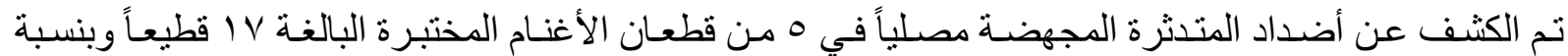

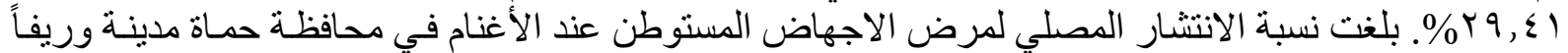

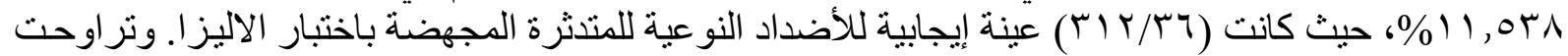

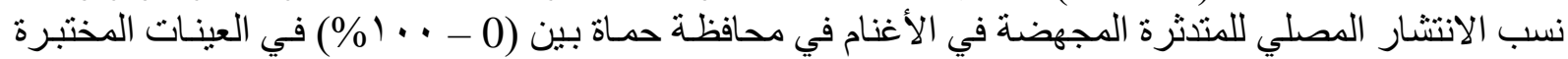

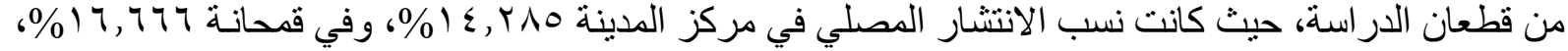

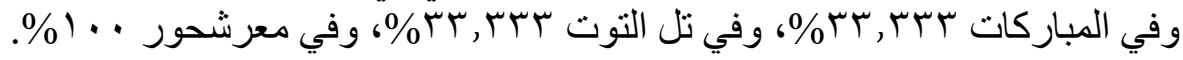

وكانت أعلى نسبة لانتثار الاجهاض الستوطن عند الأغنام في فصل الثتاء (r, Or=OR)، وأخطر مرحلة عمرية ما بين r ـ ع سنو لعات من العمر.

الكلمات المفتاحية: المندثرة المجهضة، الاجهاض المستوطن عند الأغنام، الانتشار المصلي. 